\title{
Gluten and the Gut: A Brief Review of Gluten-Related Gastrointestinal Disorders
}

\author{
Niraj James Shah* and KumarPallav \\ Department of Medicine, Division of Digestive Diseases, The University of Mississippi Medical Center, 2500 North State \\ Street, Jackson, MS 39216
}

Received: 09 June 2017; Accepted: 21 June 2017; Published: 07 July 2017

Corresponding author: Niraj James Shah, MD, Assistant Professor of Medicine, Department of Medicine, Division of Digestive Diseases, The University of Mississippi Medical Center, 2500 North State Street, Jackson, MS 39216,Tel: 001-601-984-4540 (extension 7915); Fax: 001- 601-984-4548; E-mail : jnshah@umc.edu, nirajjames@gmail.com

\section{Abstract}

Celiac disease (CD) was the first gluten-related disorder to be described. Presently the realm of gluten-related disorders also includes non-celiac gluten sensitivity (NCGS) and wheat allergy (WA). CD is a multisystem immune mediated enteropathy observed in genetically susceptible individuals exposed to dietary gluten present in barley, rye and wheat. Although the prevalence of $\mathrm{CD}$ is on the rise, it still largely remains under diagnosed given that many cases can be silent, subtle or atypical. The Pathophysiology of CD includes both innate and adaptive immune response to dietary gluten. Patients present with a wide variety of intestinal and extra-intestinal symptoms and are at risk for non-Hodgkin's lymphoma and small intestinal adenocarcinoma. The corner stone for treatment of CD is a gluten-free diet (GFD). NCGS is an emerging condition associated with gluten ingestion and the diagnosis of which is based on exclusion of $\mathrm{CD}$ and WA. Further evidence and studies are required to fully appreciate the clinical entity of NCGS and WA to detail its epidemiology and pathogenesis. The symptoms of NCGS and WA may overlap with CD and hence it is imperative to differentiate these clinical entities and select patients for appropriate management.

Keywords: Celiac disease, gluten related disorder, non-celiac gluten sensitivity, wheat allergy, gluten, epidemiology, clinical features, Pathophysiology, management, gluten free diet.

Core tip: $C D$ is largely under-diagnosed while the incidence and prevalence of gluten-related disorders are on the rise. A clear understanding of the various clinical presentations of gluten-related disorders can help differentiate CD from NCGS and WA. The management for these conditions differs and hence accurate diagnosis leads to improved patient outcomes with avoidance of longterm complications as well as unnecessary testing which can be both invasive and expensive.

\section{Materials and Methods}

\section{Literature search}

We conducted online electronic searches (published manuscripts in English) of the Cochrane Library, pub med and manual searches of selected specialty journals to identify any pertinent literature. The search was conducted using the key words 'celiac disease', 'gluten related disorder', 'non celiac gluten sensitivity', 'wheat allergy', 'gluten', , 'gluten free diet'. Studies not published in English or published only in the abstract form were excluded. We also conducted a focused review of available references to identify subsequent pertinent papers.

\section{Celiac Disease}

The term celiac is derived from the Greek word "koiliaks" meaning "abdominal". It was first described in the second century in modern day Turkey by a Greek physician Aretaeus of Cappadocia [1]. In 1888, Samuel Gee; a pediatrician from the United Kingdom gave the first modern-day description of the condition and associated diet to the treatment of celiac disease [1]. Later a Dutch pediatrician Dr. Willem-Karel Dicke around the 1944 Dutch famine linked wheat to the etiology of celiac disease. He noted that the scarcity of wheat contributed to clinical improvement and drop of death rate among his patients [2].The link with the gluten component of wheat was made in 1952 in Birmingham, in England [3,4]. Villous atrophy was described by the British physician John W. Paulley in 1954 [5]. Its hereditary character was recognized in 1965 by MacDonald etal from the Washington school of Medicine [6].

\section{Epidemiology}

Celiac disease occurs in about $1 \%$ of the general population worldwide [7]. Data from the USA suggests CD to be more common in Caucasians as compared to African-Americans and Hispanics [8,9]. The initial prevalence of CD was low (1:4,000 to $1: 8,000)$ and was based on symptomology while the recent prevalence is higher (1:70 to 1:300) and is based on serology and biopsy findings $[8,10,11]$.CD can occur at any age while the mortality rate due to $\mathrm{CD}$ after its diagnosis is low $[12,13]$.

\section{Pathogenesis}

The estimated risk of CD in first degree relatives is between 4\%-17\% and up to $26 \%$ in relatives who are homozygous for HLA DQ2 [14,15]. Recently published studies indicate no association between age of gluten introduction, ongoing breast feeding and the development of CD [16,17]. Underlying viral infections triggering CD has been entertained for some time but lacks direct evidence [18-21]. A cross-sectional study from the USA suggests decreased risk of celiac disease in patients with helicobacter pylori colonization [22].

Storage proteins in wheat, rye and barley is referred to as gluten [23]. While it may be easy to avoid products directly derived from wheat, gluten contamination is universal. Hidden sources of gluten include contaminated oats, sauces (marinades, soy sauce), drug fillers, 
shared food preparation equipment (pasta pot, toaster, deep fryer) and processed meats [24]. Gluten is rich in glutamines and prolamines which are incompletely digested into large peptides [25]. These peptides via transcellular and paracellular route enter into the lamina propria of the small intestinal wall, where the tissue transglutaminase (TTG) deaminates gliadin thereby increasing its immunogenicity. The deamidated gliadin peptides (DGP) undergo processing within the antigen processing cells (apcs) and are presented to the $\mathrm{T}$ lymphocytes in association with the HLA DQ2 or DQ8 molecules present on the surface of apcs [26,27]. The immunological cascade continues with CD4 positive T cells (specific for gliadin peptides) contributing to the production of pro-inflammatory cytokines and release of metalloproteinases leading to tissue injury [2830].This injury to the small intestinal Villi leads to loss of the absorptive surface area, malabsorption (of micronutrients, fat soluble vitamins, iron, vitamin B 12 and folic acid), diarrhea, weight loss along with abdominal pain and bloating [31-33]. CD has been recognized to be one of the common causes of malabsorption [34].

\section{Diagnosis of Celiac Disease}

Immunoglobulin A (IgA) anti-tissue transglutaminase (TTG) antibody has a high sensitivity (>95\%) and specificity (>95\%) and hence is the recommended screening test in patients who do not have concomitant IgA deficiency [35]. However, studies from USA and Europe indicate the prevalence of selective IgA deficiency (sigad) to be between $1.9 \%$ and $3 \%$, which is approximately 10-15 times higher than the general population [36-39] .In patients with sigad; IgG-based testing of IgG anti-TTG or IgG DGP (deamidated gliadin peptide) should be performed [40]. IgA anti endomysial antibodies is a highly specific test (specificity approaches a $100 \%$ ); but is reserved to confirm active celiac disease as it is expensive, time consuming and operator-dependent [41].

An upper endoscopy with duodenal biopsies (one or two from the duodenal bulb and at least another four biopsies from the dista duodenum) is essential for the confirmation of the diagnosis of CD [40]. The characteristic histological finding consists of $>25$ intraepithelia lymphocytes (IEL) per 100 enterocytes with elongation of crypts and villous atrophy. Absence of villous atrophy in the presence of IEL is not specific for CD and other causes should be considered [40]. Despite CD is considered to be the most common etiology of villous atrophy; other possible causes of villous atrophy with absent celiac serologies can be seen in common variable immunodeficiency (CVID), autoimmune enteropathy, small intestinal bacterial over-growth, infection, intestinal lymphoma collagenous sprue, Crohn's disease and tropical sprue [36].

Histologically duodenal biopsies are graded into 5 stages (Marsh's criteria42)

-Stage 0- Normal

-Stage 1 - increased percentage of IEL > 30\%

-Stage 2- Increased presence of inflammatory cells and crypt proliferation with preserved villous architecture

-Stage 3- Mild (A), moderate (B) or subtotal (C) villous atrophy

-Stage 4- Total mucosal hypoplasia
Genetic testing for HLA-DQ2 and HLA-DQ8 has a high negative predictive value and hence a negative test helps exclude the diagnosis of CD [43-47]. HLA genetic testing is most useful in patients with discrepancy with celiac specific serology with histology, before initiating a gluten free diet and also in excluding refractory celiac. Testing for HLA-DQ2 and HLADQ8 has been employed in screening for family members of patients with CD and in patients with Down's syndrome.

Most histologic and serologic alterations of CD normalize on a gluten free diet [7]. Many patients get tested and evaluated with histology while on a GFD and hence have negative serology and histology but are positive for HLA-DQ2 or HLA DQ-8. These patients require a gluten challenge with a diet containing as little as 3gms of gluten per day for 6-8 weeks when a repeat serology may become positive $[48,49]$.

Duodenal biopsies to rule out CD should be performed in all patients with dyspepsia, undergoing upper gastrointestinal endoscopy as GFD is largely helpful [31].

\section{Management of celiac disease}

Adherence to a lifelong GFD (with avoidance of wheat, barley and rye) is the only effective treatment as we do not have any proven medications that could halt or alter gluten related mucosal injury [40]. GFD improves symptomology, reduces mucosal damage and eliminates risks for osteoporosis and bowel cancers associated with long term active CD [5056]. All newly diagnosed patients should undergo a formal investigation for micronutrient deficiencies including serum iron, folic acid, vitamin D and vitamin B12 [40]. Nutritional assessment and counseling with a skilled registered dietician is imperative in educating patients and aids patients adhering to a GFD [57].

Absolute adherence to a GFD is difficult as gluten contamination is frequent. A persistently positive celiac serology one year after initiation of GFD may indicate gluten contamination [58] and hence requires a repeat referral to a dietician to assess for adequate knowledge and adherence to a GFD. Regular follow up for symptom review and monitoring of patients with celiac serology (IgA TTG or IgA or IgG DGP antibodies) is indicated. A repeat upper endoscopy with histology is only indicated with persistent or worsening symptoms despite confirmed adherence to a GFD.

GFD is the only intervention available. Barriers include its availability, its restriction in social situations and cost [59]. This overtime has a profound psychosocial effect on the patient's life adversely affecting his quality of life [59]. Manipulation of the mechanisms of tight junction regulators, glutenases, gluten sequestrants and immunotherapy using vaccines and nano particles are some of the novel therapeutic adjuncts to a GFD [60].

\section{Non-responsive celiac disease (NRCD)}

NRCD is defined as the persistence of clinical and laboratory abnormalities of CD even after adherence to a GFD for 6-12 months [58,6163]. It affects $7-30 \%$ of patients on a GFD for CD $[58,61,62]$. The most common etiology is purposeful or hidden gluten ingestion accounting for $35 \%$ to $50 \%$ of the cases, hence a dietary referral is warranted in these cases $[58,61,62]$. The evaluation should also include reconfirmation of the previous diagnosis of $\mathrm{CD}$ and ruling out other common causes of similar 
symptomology including small bowel bacterial overgrowth, food allergies, pancreatic insufficiency, irritable bowel syndrome and refractory celiac disease [58,61-65]. Since CD and microscopic colitis (MC) overlap[66,67] MC should be considered in patients with NRCD while CD is considered in patients with unresponsive MC [68].

\section{Refractory celiac disease (RCD)}

RCD is defined as persistent clinical symptoms and signs of malabsorption with histological evidence of small bowel villous atrophy (related disorders including overt lymphoma needs to be ruled out) even after adherence to a GFD for more than 12 months [7,61,69]. It affects $1-2 \%$ of patients on a GFD for CD $[64,70,71]$.The clinical presentation and course of patients with RCD is much worse when compared to patients with NRCD [61,64]. The ongoing symptoms of RCD is independent of glutenwithdrawal; with only mild and transient response to gluten withdrawal and subsequent return of severe symptoms [72].RCD is subdivided into two sub-groups:

-Type I RCD

-Histology reveals IEL with normal surface T-cell receptors and normal CD3 and CD 8 expression [71,73-75]

-Management includes avoidance of gluten exposure and repletion of nutritional deficiencies $[61,64,70,71,73]$.

-Type II RCD

-Histology reveals IEL with loss of surface T-cell receptors and abnormal phenotypic expression and differentiation of CD3 and CD8 positive intraepithelial T cells[73-75]

-Management is similar to Type I RCD. Type II RCD is less likely to respond to treatment and carries a poorer prognosis; largely explained by its progression to enteropathy-associated T-cell lymphoma [70,71,73,76-78]

Prednisone is used in severe cases of RCD. In cases of incomplete response; other immunosuppressive agents including azathioprine, budesonide, 6-mercaptapurine, Mesalamine, cyclosporine and anti-tumor necrosis factor antibodies have been used [69-71,76,79-83].

\section{Ulcerative jejunitis}

Ulcerative jejunitis is usually seen in middle aged patients with CD refractory to steroids [84]. Monoclonal aberrant T-cell abnormality is the postulated pathogenesis $[53,85]$. Patients continue to experience symptoms of diarrhea, abdominal pain and malabsorption despite being on a GFD [86,87]. Workup includes an exclusion of malignancy $[69,76,88,89]$ (EATL and small bowel adenocarcinoma) with an abdominal CT enterography or MR Enterography. Endoscopy reveals multiple benign ulcers concentrated mainly in the jejunum [70,71]; and if negative should be followed by a capsule endoscopy $[90,91]$. It usually carries a poor prognosis; while surgical resection of localized ulcerations and structured small bowel improves prognosis $[71,76,89,92]$.

\section{Celiac crisis}

Patients with CD can present with celiac crisis; a life threatening syndrome presenting with severe diarrhea, metabolic and electrolyte derangements requiring hospitalization $[93,94]$. Although celiac crisis is usually seen in children; physicians should have a high index of suspicion even in adults with CD as this would carry a high morbidity [95-99]. Hence this warrants prompt diagnosis and intervention. Limited data suggests lesser frequency of celiac crisis which has been attributed to recent improved diagnostic modalities [97]. Management includes fluid and electrolyte replacement, nutritional support and corticosteroids [100].

\section{Non-Celiac Gluten Sensitivity (NCGS)}

NCGS was first described as individual cases in the late 1970's and later as a case series in 1980 [101-103]. However, since 2010 a rapid increase in interest and case series has been published. The prevalence of NCGS is unknown and is difficult to estimate. Results from the Continuous National Health and Nutrition Examination Survey in the United States and various other surveys from the United Kingdom and other parts of Europe indicate wide range of prevalence rates with identifiable risk factors to be a young or middle aged female patient with irritable bowel syndrome (IBS) [104-107].

NCGS is a clinical entity induced by the ingestion of dietary gluten leading to intestinal and/or extra-intestinal symptoms that resolve with a GFD, and when CD and WA have been ruled out [108-111].

The pathogenesis is largely unknown. In 2011, Sapone etal suggested an innate immune response [112] with activation of toll like receptors while other studies have suggested increased intestinal permeability to be responsible [113-116]. Increased CD3 positive IEL105,112-117 and increased interferon $\gamma$ to a gluten challenge [117] suggests gut mucosal activation.

NCGS patients present with gastrointestinal symptoms (abdominal pain, bloating, altered bowel habits) and extra intestinal symptoms (fatigue, headaches, joint pain, mood disorders, eczema) [107,110,111].

Since we do not have any definite clinical, serological, endoscopic or histological criteria for NCGS; its diagnosis is mainly based on symptoms related to gluten consumption and withdrawal and the exclusion of CD and WA. Patients have a negative IgA TTG and EMA and may in up to 50\% have positive IgG DGP and rarely positive IgA DGP [107,118,119] . The endoscopy is almost always normal with preserved Villi while a mild increase in IEL 119 may be observed. Up to 50\% may have HLA-DQ2 and HLA-DQ8 [110].

Despite the proposed double-blind, placebo-controlled glutenchallenge trials being considered for the diagnosis of NCGS [110]; a recent meta-analysis published in March of 2017 comprising of 1312 adults from 10 trials indicated that more than $80 \%$ of the patients with suspected NCGS could not be definitely diagnosed [120]. However the proposed double blind, placebo-controlled gluten-challenge can distinguish NCGS from IBS 105. IBS-like symptoms are common in patients with NCGS. Gluten containing diets increase intestinal permeability and worsen symptoms in IBS-D subpopulation [121]. NCGS does not lead to malabsorption given lack of intestinal inflammation and for the same reason there is no risk for malignancy if left untreated. Unlike CD where the goal of treatment is complete exclusion of obvious and hidden gluten from one's diet, the treatment of NCGS revolves around symptom management. 


\section{Wheat Allergy}

Since 10,000 years when humans started agriculture in Mesopotamia; wheat has become a staple diet and is the most widely grown crop [122]. Processed wheat is consumed as bread, pasta, pizza, couscous and beer $[122,123]$.

Food allergy to wheat is typically characterized by a T helper type 2 (Th2) lymphocytic inflammation [124-128] in genetically predisposed $[125,129,130]$ individuals. The subsequent cascade of Th2 activation could either lead to an IgE mediated (immediate response with wheatspecific IgE antibodies) or a non IgE mediated allergy (chronic cellular inflammation with presence of lymphocytes and eosinophils) [124-128].

The prevalence of ingested wheat allergy [IgE mediated anaphylaxis, wheat-dependent exercise-induced anaphylaxis (WDEIA, urticaria and angioedema is higher in children; who generally out-grow it by schoolage [131-135]. Repeated exposure to wheat flour in bakers and pasta factory workers can induce an IgE mediated respiratory allergy (includes baker's asthma and baker's rhinitis) [136,137]. Non-IgE mediated wheat allergy has been postulated to lead to eosinophilic esophagitis (EOE) or eosinophilic gastritis (EG).

Patients give a history of immediate symptoms (due to release of histamine, platelet activator factors and leukotrienes) secondary to IgE mediated food allergy $[138,139]$.

The diagnosis of IgE mediated wheat allergy is based on a combination of patient history with specific and reproducible symptoms on exposure to wheat and immunological tests including food challenges as detailed below:

1.Skin prick test (SPT): It has a low predictive value and lacks standardization (with varied protein content) [140].
2.In vitro specific Immunoglobulin E (sige): These assays when compared to SPT are more sensitive $(75 \%-80 \%)$ but less specific $(60 \%)$ due to cross-reactivity demonstrated in wheat flour and grass pollen-sensitivity $[141,142]$.

3.Molecular-based allergy (MA) diagnostics incorporates wheat flour extracts like omega-5 gliadin (Tri a 19), nsltp (Tri a 14), alpha-amylase/ trypsin inhibitor (Tri a aa/TI) [137,143].

4.Functional assays (FA) or food challenge test: In vitro flow cytometry assisted basophile activation test (BAT). FA's are considered only when SPT, stge and MA are inconclusive. FA involves a double blind placebo controlled food challenge. It requires a control setting as the test has the potential to be dangerous $[144,145]$.

Currently, the management of WA is based on avoidance of wheat. Patients should undergo dietary advice and referrals to identify relevant food allergens [146]. In the USA since 2005, Food Allergen Labelᄀing and Consumer Protection Act of 2004 has been enacted to help with reading labels to prevent the accidental expo sure to foods for eight of the most common food allergens (milk, egg, peanuts, tree nuts, fish, shellfish, soy, and wheat) [146].Certain modalities including immunotherapy (oral immunotherapy (OIT), sublingual immuno 7 therapy (SLIT), and epicutaneous immunotherapy (EPIT).) Are presently in the pipeline and are promising ways to treat IgE mediated reactions to wheat [147].

The clinical distinction between CD, NCGS and WA is vital in formulating a plan for management. A guide to the differential diagnosis of major gastrointestinal gluten-related disorders is detailed in (Table 1). WA may be diagnosed on the basis of a history and physical suggestive of an allergic process and confirmed with IgE based testing. On the contrary, CD and NCGS can be clinically indistinguishable. The recently published diagnostic model (Figure 1) for symptoms responsive to a GFD by Kabbani et al can be very helpful in differentiating CD from NCGS.

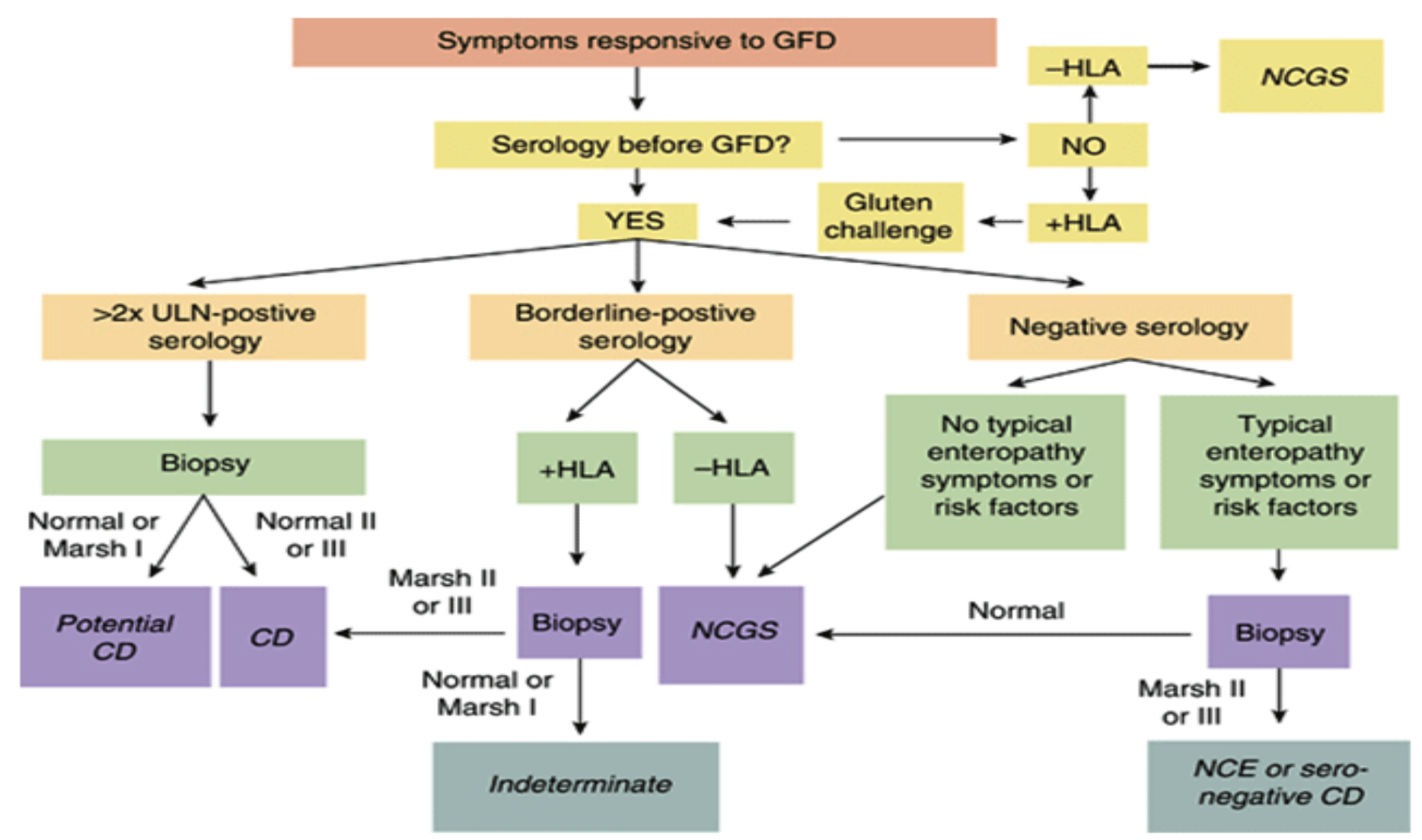

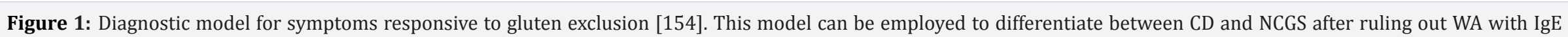
assays when it is suspected based on signs of an allergic etiology such as hives, urticaria, angioedema or eczema. 
Table1: Guide to differential diagnosis of CD, NCGS and WA

\begin{tabular}{|c|c|c|c|}
\hline & Celiac disease (CD) & Non-celiac gluten sensitivity (NCGS) & Wheat allergy (WA) \\
\hline Epidemiology & $\begin{array}{l}1 \% \text { world-wide prevalence. Estimated to be } \\
\text { higher }\end{array}$ & $\begin{array}{l}\text { Largely not known. Prevalence of } \\
0.5 \% \text { in the USA (national health and } \\
\text { nutrition examination survey report) }\end{array}$ & $\begin{array}{l}3 \% \text { prevalence in the usa; as per the spt. Other studies } \\
\text { indicate } 0.2 \%-1 \% \text { of the pediatric population } 148 \text { - } \\
153\end{array}$ \\
\hline Pathology & $\begin{array}{l}\text { Innate and adaptive immune response. Non } \\
\text { Th2 response }\end{array}$ & $\begin{array}{l}\text { Likely innate immunity with no } \\
\text { adaptive immune response }\end{array}$ & Food allergy, Allergic immunity, IgE mediated \\
\hline $\begin{array}{l}\text { Genetics HLA-DQ2, } \\
\text { HLA-DQ8 Testing }\end{array}$ & $\begin{array}{l}\text { Negative HLA testing essentially rules out } \\
\text { CD }\end{array}$ & $\begin{array}{l}\text { Negative HLA testing does not rule out } \\
\text { NCGS }\end{array}$ & Negative HLA testing does not rule out WA \\
\hline Clinical features & $\begin{array}{l}\text { Abdominal pain, altered bowel habits, } \\
\text { fatigue, headaches, anemia, bone and joint } \\
\text { pain, mood disorders, eczema or rash }\end{array}$ & $\begin{array}{l}\text { Abdominal pain, altered bowel habits, } \\
\text { fatigue, headaches, anemia, bone and } \\
\text { joint pain, mood disorders, eczema or } \\
\text { rash }\end{array}$ & Asthma, rhinitis, urticaria, angioedema, \\
\hline Serology & Positive IgA TTG and EMA, IgG and IgA DGP & $\begin{array}{l}\text { Negative IgA TTG and EMA, may have } \\
\text { up to } 50 \% \text { positive IgG DGP and rarely } \\
\text { positive IgA DGP }\end{array}$ & Positive IgE based assays \\
\hline Histology & $\begin{array}{l}\text { Partial or subtotal villous atrophy with } \\
\text { crypt hyperplasia }\end{array}$ & $\begin{array}{l}\text { Normal Villi with rare isolated } \\
\text { intraepithelial lymphocytosis }\end{array}$ & Normal \\
\hline Diagnosis based on & $\begin{array}{l}\text { History, serology and histology, HLA } \\
\text { genotyping if serological and histological } \\
\text { discrepancy exists }\end{array}$ & $\begin{array}{l}\text { Diagnosis based on exclusion of CD } \\
\text { and WA }\end{array}$ & $\begin{array}{l}\text { Skin prick test, in vitro specific IgE assays and } \\
\text { functional assays }\end{array}$ \\
\hline Management & $\begin{array}{l}\text { Strict Gluten-free diet with aim of excluding } \\
\text { any and all gluten from the diet to achieve } \\
\text { histologic remission }\end{array}$ & $\begin{array}{l}\text { Gluten avoidanceto achieve } \\
\text { Symptomatic remission }\end{array}$ & $\begin{array}{l}\text { Avoidance of wheat. Possible Immunotherapy in } \\
\text { future }\end{array}$ \\
\hline Complications & $\begin{array}{l}\text { Osteoporosis, infertility Associated } \\
\text { with intestinal malignancy- } \\
\text { adenocarcinoma, esophageal cancers, B-cell } \\
\text { and T-cell lymphomas }\end{array}$ & $\begin{array}{l}\text { Not associated with malabsorption or } \\
\text { nutritional deficiencies }\end{array}$ & No comorbidities, rare anaphylaxis \\
\hline Prognosis & Excellent when recognized & Excellent & Excellent \\
\hline
\end{tabular}

\section{Conclusion}

Though the prevalence of gluten related gastrointestinal disorders is increasing; yet many believe this is largely an undiagnosed clinical entity. Clinicians should have a high index of suspicion for patients presenting with possible symptoms of gluten related disorders and follow the algorithm to diagnose and differentiate CD, NCGS and WA. It is essential to accurately diagnose CD, NCGS and WA as the management differs. Further research and studies will lead to enhanced understanding of gluten related disorders and facilitate better treatment selection and attainment of long-term therapeutic goals. Early and ongoing counseling with skilled celiac dietitians will aid symptom control and prevent the progression of disease reducing morbidity and improving the quality of life.

\section{References}

1. Smits BJ. History of coeliac disease. BMJ. 1989;298(6670):387

2. WK D. Simple dietary treatment for the syndrome of GheeHerter. Ned Tijdschr Geneeskd Vol 1941;85:1715

3. Dicke WK WH, Van De Kamer JH. Coeliac disease. II. The presence in wheat of a factor having a deleterious effect in cases of coeliac disease. Acta Paediatr. 1953;42(1):34-42

4. Van De Kamer JH WH, Dicke WK. Coeliac disease. IV. An investigation into the injurious constituents of wheat in connection with their action on patients with coeliac disease. Acta Paediatr. 1953;42(3):223-31

5. Paulley JW. Observation on the aetiology of idiopathic steatorrhoea; jejunal and lymph-node biopsies. Br Med J. 1954;2(4900):1318-21

6. Macdonald WC, Dobbins WO, 3rd, Rubin CE. Studies of the Familial Nature of
Celiac Sprue Using Biopsy of the Small Intestine. N Engl J Med. 1965;272:44856; Doi:10.1056/NEJM196503042720903

7. Ludvigsson JF, Leffler DA, Bai JC, Federico Biagi, Alessio Fasano, Peter H R Green, et al. The Oslo definitions for coeliac disease and related terms. Gut. 2013;62:43-52

8. Rubio-Tapia A, Ludvigsson JF, Brantner TL, Murray JA, Everhart JE. The prevalence of celiac disease in the United States. Am J Gastroenterol. 2012;107(10):1538-44;Doi: 10.1038/ajg.2012.219

9. Mardini HE, Westgate P, Grigorian AY. Racial Differences in the Prevalence of Celiac Disease in the US Population: National Health and Nutrition Examination Survey (NHANES) 2009-2012. Dig Dis Sci. 2015 J;60(6):173842;Doi: 10.1007/s10620-014-3514-7

10.Ascher H, Kristiansson B. Childhood coeliac disease in Sweden. Lancet. 1994 ;344(8918):340-341

11.Gujral N, Freeman HJ, Thomson AB. Celiac disease: prevalence, diagnosis, pathogenesis and treatment. World J Gastroenterol. 2012;18(42):6036-59; Doi: 10.3748/wjg.v18.i42.6036

12.Ludvigsson JF, Montgomery SM, Ekbom A, Brandt L, Granath F. Smallintestinal histopathology and mortality risk in celiac disease. JAMA. 2009 Sep;302(11):1171-8. Doi: 10.1001/jama.2009.1320

13.Abdul Sultan A, Crooks CJ, Card T, Tata LJ, Fleming KM, West J. Causes of death in people with coeliac disease in England compared with the general population: a competing risk analysis. Gut. 2015;64(8):1220-6;Doi: 10.1136/ gutjnl-2014-308285

14.Fasano A, Berti I, Gerarduzzi T, Not T, Colletti RB, Drago S, et al. Prevalence 
of celiac disease in at-risk and not-at-risk groups in the United States: a large multicenter study. Arch Intern Med. 2003;163(3):286-92

15.Biagi F, Campanella J, Bianchi PI, Zanellati G, Capriglione I, Klersy C, et al. The incidence of coeliac disease in adult first degree relatives. Dig Liver Dis. 2007;40 (2): 97-100; Doi: 10.1016/j.dld.2007.10.004

16.Vriezinga SL, Auricchio R, Bravi E, Castillejo G, Chmielewska A, Escobar PC, et al. Randomized feeding intervention in infants at high risk for celiac disease. $\mathrm{N}$ Engl J Med. 2014; 371:1304-1315; Doi: 10.1056/NEJMoa1404172

17.Lionetti E, Castellaneta S, Francavilla R, Pulvirenti A, Tonutti E, Amarri S, et al Introduction of gluten, HLA status, and the risk of celiac disease in children. N Engl J Med. 2014; 371:1295-1303; Doi: 10.1056/NEJMoa1400697

18.Hyoty H, Hiltunen M, Knip M, Laakkonen M, Vähäsalo P, Karjalainen J, et al. A prospective study of the role of coxsackie $B$ and other enterovirus infections in the pathogenesis of IDDM. Childhood Diabetes in Finland (DiMe) Study Group. Diabetes. 1995;44(6):652-657

19.Kagnoff MF, Paterson YJ, Kumar PJ, Kasarda DD, Carbone FR, Unsworth DJ, et al. Evidence for the role of a human intestinal adenovirus in the pathogenesis of coeliac disease. Gut. 1987;28(8):995-1001

20.Stene LC, Honeyman MC, Hoffenberg EJ, Haas JE, Sokol RJ, Emery $\mathrm{L}$, et al. Rotavirus infection frequency and risk of celiac disease autoimmunity in early childhood: a longitudinal study. Am J Gastroenterol. 2006;101(10):2333-2340;Doi:10.1111/j.1572-0241.2006.00741.x

21.Riddle MS, Murray JA, Porter CK. The incidence and risk of celiac disease in a healthy US adult population. Am J Gastroenterol. 2012;107(8):1248-1255;Doi 10.1038/ajg.2012.130

22.Lebwohl B, Blaser MJ, Ludvigsson JF, Green PH, Rundle A, Sonnenberg A, et al. Decreased risk of celiac disease in patients with Helicobacter pylori colonization. Am J Epidemiol. 2013;178(12):1721-1730;Doi: 10.1093/aje/ kwt234

23.Biesiekierski JR. What is gluten? J Gastroenterol Hepatol. 2017;32 Suppl 1:78 81;Doi: 10.1111/jgh.13703

24.Lebwohl B, Ludvigsson JF, Green PH. Celiac disease and non-celiac gluten sensitivity. BMJ. 2015;351:h4347; doi: 10.1136/bmj.h4347

25.Shan L, Molberg 0, Parrot I, Hausch F, Filiz F, Gray GM, et al. Structural basis for gluten intolerance in celiac sprue. Science. 2002;297(5590):22752279;Doi:10.1126/science.1074129

26.Matysiak-Budnik T, Moura IC, Arcos-Fajardo M, Lebreton C, Ménard S, Candalh C, et al. Secretory IgA mediates retrotranscytosis of intact gliadin peptides via the transferrin receptor in celiac disease. J Exp Med. 2008;205(1):143-54;Doi: 10.1084/jem.20071204

27.Visser J, Rozing J, Sapone A, Lammers K, Fasano A. Tight junctions, intestinal permeability, and autoimmunity: celiac disease and type 1 diabetes paradigms. Ann N Y Acad Sci. 2009;1165:195-205;Doi: 10.1111/j.17496632.2009.04037.x

28.Sollid LM. Coeliac disease: dissecting a complex inflammatory disorder. Nat Rev Immunol. 2002;2(9):647-655;Doi: 10.1038/nri885

29.Nilsen EM, Jahnsen FL, Lundin KE, Johansen FE, Fausa O, Sollid LM, et al. Gluten induces an intestinal cytokine response strongly dominated by interferon gamma in patients with celiac disease. Gastroenterology. 1998;115(3):551563

30.Mohamed BM, Feighery C, Kelly J, Coates C, O'Shea U, Barnes L, et al. Increased protein expression of matrix metalloproteinases $-1,-3$, and -9 and TIMP-1 in patients with gluten-sensitive enteropathy. Dig Dis Sci. 2006 Oct;51(10):18621868;Doi: 10.1007/s10620-005-9038-4

31.Murray JA, Watson T, Clearman B, Mitros F. Effect of a gluten-free diet on gastrointestinal symptoms in celiac disease. Am J Clin Nutr. 2004;79(4):669673

32.Rostom A, Murray JA, Kagnoff MF. American Gastroenterological Association (AGA) Institute technical review on the diagnosis and management of celiac disease. Gastroenterology. 2006;131(6):1981-2002;Doi: 10.1053/j. gastro.2006.10.004

33.Reilly NR, Fasano A, Green PH. Presentation of celiac disease. Gastrointest Endosc Clin N Am. 2012;22(4):613-621;Doi: 10.1016/j.giec.2012.07.008

34.Di Sabatino A, Corazza GR. Coeliac disease. Lancet. 2009;373(9673):14801493;Doi:10.1016/S0140-6736(09)60254-3

35.Zintzaras E, Germenis AE. Performance of antibodies against tissue transglutaminase for the diagnosis of celiac disease: meta-analysis. Clin Vaccine Immunol. 2006;13(2):187-192; Doi:10.1128/CVI.13.2.187-192.2006

36.Pallav K, Xu H, Leffler DA, Kabbani T, Kelly CP. Immunoglobulin A deficiency in celiac disease in the United States. J Gastroenterol Hepatol. 2016;31(1):133137;Doi: 10.1111/jgh.13176

37.Heneghan MA, Stevens FM, Cryan EM, Warner RH, McCarthy CF. Celiac sprue and immunodeficiency states: a 25-year review. J Clin Gastroenterol. 1997;25(2):421-425

38.Chow MA, Lebwohl B, Reilly NR, Green PH. Immunoglobulin A deficiency in celiac disease. J Clin Gastroenterol. 2012;46(10):850-854;Doi: 10.1097/ MCG.0b013e31824b2277

39.Cataldo F, Marino V, Ventura A, Bottaro G, Corazza GR. Prevalence and clinical features of selective immunoglobulin A deficiency in coeliac disease: an Italian multicentre study. Italian Society of Paediatric Gastroenterology and Hepatology (SIGEP) and "Club del Tenue" Working Groups on Coeliac Disease. Gut. 1998 Mar;42(3):362-365

40.Rubio-Tapia A, Hill ID, Kelly CP, Calderwood AH, Murray JA, American College of G. ACG clinical guidelines: diagnosis and management of celiac disease. Am J Gastroenterol. 2013;108(5):656-676;Doi: 10.1038/ajg.2013.79

41.Giersiepen K, Lelgemann M, Stuhldreher N, Ronfani L, Husby S, Koletzko S, et al. Accuracy of diagnostic antibody tests for coeliac disease in children: summary of an evidence report. J Pediatr Gastroenterol Nutr. 2012;54(2):229241;Doi: 10.1097/MPG.0b013e318216f2e5

42.Marsh MN. Gluten, major histocompatibility complex, and the small intestine. A molecular and immunobiologic approach to the spectrum of gluten sensitivity ('celiac sprue'). Gastroenterology. 1992;102(1):330-354

43.Rubio-Tapia A, Rahim MW, See JA, Lahr BD, Wu TT, Murray JA. Mucosal recovery and mortality in adults with celiac disease after treatment with a gluten-free diet. Am J Gastroenterol. 2010;105(6):1412-1420;Doi: 10.1038/ajg.2010.10

44.Kaukinen K, Partanen J, Maki M, Collin P. HLA-DQ typing in the diagnosis of 
celiac disease. Am J Gastroenterol. 2002;97(3):695-699; Doi:10.1111/j.15720241.2002.05471.x

45.Karell K, Louka AS, Moodie SJ, Ascher H, Clot F, Greco L et al. HLA types in celiac disease patients not carrying the DQA1*05-DQB1*02 (DQ2) heterodimer: results from the European Genetics Cluster on Celiac Disease. Hum Immunol. 2003;64(4):469-477

46.Green PH, Cellier C. Celiac disease. N Engl J Med. 2007;357(17):1731-1743; Doi:10.1056/NEJMra071600

47.Pallav K, Kabbani T, Tariq S, Vanga R, Kelly CP, Leffler DA. Clinical utility of celiac disease-associated HLA testing. Dig Dis Sci. 2014;59(9):2199-206;Doi: 10.1007/s10620-014-3143-1

48.Leffler D, Schuppan D, Pallav K, Najarian R, Goldsmith JD, Hansen J, et al. Kinetics of the histological, serological and symptomatic responses to gluten challenge in adults with coeliac disease. Gut. 2013;62(7):996-1004;Doi: 10.1136/gutjnl-2012-302196

49.Rujner J, Socha J, Romanczuk W, Stolarczyk A, Woźniewicz B, Gregorek H, et al.Individual sensitivity of jejunal mucosa to small doses of gluten in coeliac disease. Wiad Lek. 2002;55(9-10):554-60

50.Ludvigsson JF. Mortality and malignancy in celiac disease. Gastrointest Endosc Clin N Am. 2012 ;22(4):705-722;Doi: 10.1016/j.giec.2012.07.005

51.West J, Logan RF, Smith CJ, Hubbard RB, Card TR. Malignancy and mortality in people with coeliac disease: population based cohort study. BMJ. 2004;329(7468):716-719;Doi: 10.1136/bmj.38169.486701.7C

52.Askling J, Linet M, Gridley G, Halstensen TS, Ekstrom K, Ekbom A. Cancer incidence in a population-based cohort of individuals hospitalized with celiac disease or dermatitis herpetiformis. Gastroenterology. 2002;123(5):1428 1435

53.Corrao G, Corazza GR, Bagnardi V, Brusco G, Ciacci C, Cottone M, et al. Mortality in patients with coeliac disease and their relatives: a cohort study. Lancet. 2001;358(9279):356-361

54.Bardella MT, Fredella C, Prampolini L, Molteni N, Giunta AM, Bianchi PA. Body composition and dietary intakes in adult celiac disease patients consuming a strict gluten-free diet. Am J Clin Nutr. 2000;72(4):937-939

55.Barera G, Mora S, Brambilla P, Ricotti A, Menni L, Beccio S, et al. Body composition in children with celiac disease and the effects of a gluten-free diet: a prospective case-control study. Am J Clin Nutr. 2000;72(1):71-75

56.Rea F, Polito C, Marotta A, Di Toro A, Iovene A, Collini R, et al. Restoration of body composition in celiac children after one year of gluten-free diet. J Pediatr Gastroenterol Nutr. 1996;23(4):408-412

57.Simpson S, Thompson T. Nutrition assessment in celiac disease. Gastrointest Endosc Clin N Am. 2012; 22(4):797-809;Doi: 10.1016/j.giec.2012.07.010

58.Abdulkarim AS, Burgart LJ, See J, Murray JA. Etiology of nonresponsive celiac disease: results of a systematic approach. Am J Gastroenterol. 2002;97(8):20162021; Doi:10.1111/j.1572-0241.2002.05917.x

59.See JA, Kaukinen K, Makharia GK, Gibson PR, Murray JA. Practical insights into gluten-free diets. Nat Rev Gastroenterol Hepatol. 2015;12(10):580-591;Doi 10.1038/nrgastro.2015.156
60.Kurada S, Yadav A, Leffler DA. Current and novel therapeutic strategies in celiac disease. Expert Rev Clin Pharmacol. 2016; 9 (9):1211-1223. Doi: $10.1080 / 17512433.2016 .1200463$

61.Leffler DA, Dennis M, Hyett B, Kelly E, Schuppan D, Kelly CP. Etiologies and predictors of diagnosis in nonresponsive celiac disease. Clin Gastroenterol Hepatol .2007;5(4):445-450;Doi: 10.1016/j.cgh.2006.12.006

62.0'Mahony S, Howdle PD, Losowsky MS. Review article: management of patients with non-responsive coeliac disease. Aliment Pharmacol Ther. 1996;10(5):671-680

63.Fine KD, Meyer RL, Lee EL. The prevalence and causes of chronic diarrhea in patients with celiac sprue treated with a gluten-free diet. Gastroenterology. 1997;112(6):1830-1838

64.Roshan B, Leffler DA, Jamma S, Dennis M, Sheth S, Falchuk K, et al. The incidence and clinical spectrum of refractory celiac disease in a north american referral center. Am J Gastroenterol. 2011;106(5):923-928;Doi: 10.1038/ajg.2011.104

65.Tursi A, Brandimarte G, Giorgetti G. High prevalence of small intestinal bacterial overgrowth in celiac patients with persistence of gastrointestinal symptoms after gluten withdrawal. Am J Gastroenterol. 2003;98(4):839-843; Doi:10.1111/j.1572-0241.2003.07379.x

66.Stewart M, Andrews CN, Urbanski S, Beck PL, Storr M. The association of coeliac disease and microscopic colitis: a large population-based study. Aliment Pharmacol Ther. 2011;33(12):1340-1349 ; Doi: 10.1111/j.13652036.2011.04666.x

67.Green PH, Yang J, Cheng J, Lee AR, Harper JW, Bhagat G. An association between microscopic colitis and celiac disease. Clin Gastroenterol Hepatol. 2009;7(11):1210-1216;Doi: 10.1016/j.cgh.2009.07.011

68.Pardi DS, Kelly CP. Microscopic colitis. Gastroenterology. 2011;140(4):11551165; Doi: 10.1053/j.gastro.2011.02.003

69.Trier JS, Falchuk ZM, Carey MC, Schreiber DS. Celiac sprue and refractory sprue. Gastroenterology. 1978;75(2):307-316

70.Rubio-Tapia A, Kelly DG, Lahr BD, Dogan A, Wu TT, Murray JA. Clinical staging and survival in refractory celiac disease: a single center experience. Gastroenterology.2009;136(1):99-107;352-353;Doi:10.1053/j. gastro.2008.10.013

71.Malamut G, Afchain P, Verkarre V, Lecomte T, Amiot A, Damotte D, et al. Presentation and long-term follow-up of refractory celiac disease: comparison of type I with type II. Gastroenterology. 2009;136(1):81-90;Doi: 10.1053/j. gastro.2008.09.069

72.Woodward J. Improving outcomes of refractory celiac disease - current and emerging treatment strategies. Clin Exp Gastroenterol. 2016;9:225-236;Ddoi: 10.2147/CEG.S87200

73.Cellier C, Delabesse E, Helmer C, Patey N, Matuchansky C, Jabri B, et al. Refractory sprue, coeliac disease, and enteropathy-associated T-cell lymphoma. French Coeliac Disease Study Group. Lancet. 2000 15;356(9225):203-208

74.Cellier C, Patey N, Mauvieux L, Jabri B, Delabesse E, Cervoni JP, et al. Abnormal intestinal intraepithelial lymphocytes in refractory sprue. Gastroenterology. 1998;114(3):471-481

75.Daum S, Weiss D, Hummel M, Ullrich R, Heise W, Stein H, et al. Frequency 
of clonal intraepithelial $\mathrm{T}$ lymphocyte proliferations in enteropathy-type intestinal $\mathrm{T}$ cell lymphoma, coeliac disease, and refractory sprue. Gut. 2001;49(6):804-812

76.Al-Toma A, Verbeek WH, Hadithi M, von Blomberg BM, Mulder CJ. Survival in refractory coeliac disease and enteropathy-associated T-cell lymphoma: retrospective evaluation of single-centre experience. Gut. 2007;56(10):13731378; Doi:10.1136/gut.2006.114512

77.Meresse B, Ripoche J, Heyman M, Cerf-Bensussan N. Celiac disease: from oral tolerance to intestinal inflammation, autoimmunity and lymphomagenesis. Mucosal Immunol. 2009;2(1):8-23;Doi: 10.1038/mi.2008.75

78.Daum S, Hummel M, Weiss D, Peters M, Wiedenmann B, Schäper F, et al. Refractory sprue syndrome with clonal intraepithelial lymphocytes evolving into overt enteropathy-type intestinal T-cell lymphoma. Digestion. 2000;62(1):60-65

79.Rubio-Tapia A, Murray JA. Classification and management of refractory coeliac disease. Gut. 2010 ;59(4):547-557;Doi: 10.1136/gut.2009.195131

80.Daum S, Ipczynski R, Heine B, Schulzke JD, Zeitz M, Ullrich R. Therapy with budesonide in patients with refractory sprue. Digestion. 2006;73(1):60-68; Doi:10.1159/000092639

81.Maurino E, Niveloni S, Chernavsky A, Pedreira S, Mazure R, Vazquez H, et al. Azathioprine in refractory sprue: results from a prospective, open-label study. Am J Gastroenterol. 2002 Oct;97(10):2595-602; Doi:10.1111/j.15720241.2002.06029.x

82.Wahab PJ, Crusius JB, Meijer JW, Uil JJ, Mulder CJ. Cyclosporin in the treatment of adults with refractory coeliac disease--an open pilot study. Aliment Pharmacol Ther. 2000 Jun;14(6):767-774

83.Abdallah H, Leffler D, Dennis M, Kelly CP. Refractory celiac disease. Curr Gastroenterol Rep.2007;9:401-405

84.Sigman T, Nguyen VH, Costea F, Sant'Anna A, Seidman EG. Ulcerative jejunitis in a child with celiac disease. BMC Gastroenterol. 2014;14:29;Doi: 10.1186/1471230X-14-29

85.Ashton-Key M, Diss TC, Pan L, Du MQ, Isaacson PG. Molecular analysis of T-cell clonality in ulcerative jejunitis and enteropathy-associated T-cell lymphoma. Am J Pathol. 1997;151(2):493-498

86.Bayless TM, Kapelowitz RF, Shelley WM, Ballinger WF, 2nd, Hendrix TR. Intestinal ulceration--a complication of celiac disease. N Engl J Med. 1967 May 4;276(18):996-1002; Doi:10.1056/NEJM196705042761802

87.Al-toma A, Verbeek WH, Mulder CJ. The management of complicated celiac disease. Dig Dis. 2007;25(3):230-236;Doi:10.1159/000103891

88.Gale J, Simmonds PD, Mead GM, Sweetenham JW, Wright DH. Enteropathytype intestinal T-cell lymphoma: clinical features and treatment of 31 patients in a single center. J Clin Oncol. 2000;18(4):795-803; Doi:10.1200/ JCO.2000.18.4.795

89.Baer AN, Bayless TM, Yardley JH. Intestinal ulceration and malabsorption syndromes. Gastroenterology. 1980;79:754-765

90.Culliford A, Daly J, Diamond B, Rubin M, Green PH. The value of wireless capsule endoscopy in patients with complicated celiac disease. Gastrointest Endosc. 2005;62(1):55-61
91.Daum S, Wahnschaffe U, Glasenapp R, Borchert M, Ullrich R, Zeitz M, et al. Capsule endoscopy in refractory celiac disease. Endoscopy. 2007;39(5):455458; Doi:10.1055/s-2007-966239

92.Maurino E, Niveloni S, Chernavsky AC, Sugai E, Vázquez H, Pedreira S, et al. Clinical characteristics and long-term outcome of patients with refractory sprue diagnosed at a single institution. Acta Gastroenterol Latinoam. 2006;36(1):10-22

93.Fasano A, Catassi C. Current approaches to diagnosis and treatment of celiac disease: an evolving spectrum. Gastroenterology. 2001;120(3):636-651

94.Mones RL, Atienza KV, Youssef NN, Verga B, Mercer GO, Rosh JR. Celiac crisis in the modern era. J Pediatr Gastroenterol Nutr. 2007;45:480-483;Doi: 10.1097/ MPG.0b013e318032c8e7

95.0zaslan E, Koseoglu T, Kayhan B. Coeliac crisis in adults: report of two cases. Eur J Emerg Med. 2004; 11(6):363-365

96.Gupta T, Mandot A, Desai D, Abraham P, Joshi A. Celiac crisis with hypokalemic paralysis in a young lady. Indian J Gastroenterol. 2006;25(5):259-260

97.Wolf I, Mouallem M, Farfel Z. Adult celiac disease presented with celiac crisis: severe diarrhea, hypokalemia, and acidosis. J Clin Gastroenterol. 2000;30(3):324-326

98.Al Shammeri O, Duerksen DR. Celiac crisis in an adult on immunosuppressive therapy. Can J Gastroenterol. 2008; 22(6):574-576

99.Gutiérrez S, Toro M, Cassar A, Ongay R, Isaguirre J, López C, et al. [Celiac crisis: presentation as bleeding diathesis]. Acta Gastroenterol Latinoam. 2009; 39(1):53-54

100.Jamma S, Rubio-Tapia A, Kelly CP, Murray J, Najarian R, Sheth S, et al. Celiac crisis is a rare but serious complication of celiac disease in adults. Clin Gastroenterol Hepatol.2010; 8(7):587-590; Doi:10.1016/j.cgh.2010.04.009

101.Cooper BT, Holmes GK, Fperguson R, Thompson R, Cooke WT. Proceedings: Chronic diarrhoea and gluten sensitivity. Gut. 1976; 17(5):398

102.Ellis A, Linaker $\quad$ BD. $\quad$ Non-coeliac gluten sensitivity?Lancet.1978;311:1358-1359;

103.Cooper BT, Holmes GK, Ferguson R, Thompson RA, Allan RN, Cooke WT. Gluten-sensitive diarrhea without evidence of celiac disease. Gastroenterology. 1980;79(5 Pt 1):801-806

104.Aziz I, Lewis NR, Hadjivassiliou M, Winfield SN, Rugg N, Kelsall A, et al. A UK study assessing the population prevalence of self-reported gluten sensitivity and referral characteristics to secondary care. Eur J Gastroenterol Hepatol. 2014;26(1):33-39;Doi: 10.1097/01.meg.0000435546.87251.f7

105.Biesiekierski JR, Newnham ED, Irving PM, Barrett JS, Haines M, Doecke JD, et al. Gluten causes gastrointestinal symptoms in subjects without celiac disease: a double-blind randomized placebo-controlled trial. Am J Gastroenterol. 2011;106(3):508-514;Doi: 10.1038/ajg.2010.487

106.DiGiacomo DV, Tennyson CA, Green PH, Demmer RT. Prevalence of glutenfree diet adherence among individuals without celiac disease in the USA: results from the Continuous National Health and Nutrition Examination Survey 2009-2010. Scand J Gastroenterol. 2013 Aug;48(8):921-925;Doi: $10.3109 / 00365521.2013 .809598$

107.Volta U, Bardella MT, Calabro A, Troncone R, Corazza GR, Study Group for 
Non-Celiac Gluten S. An Italian prospective multicenter survey on patients suspected of having non-celiac gluten sensitivity. BMC Med. 2014;12:85;Doi: 10.1186/1741-7015-12-85

108.Fasano A, Sapone A, Zevallos V, Schuppan D. Nonceliac gluten sensitivity. Gast roenterology.2015;148(6):1195-1204;Doi: 10.1053/j.gastro.2014.12.049

109.Volta U, De Giorgio R. New understanding of gluten sensitivity. Nat Rev Gastroenterol Hepatol. 2012 28;9(5):295-299;doi: 10.1038/nrgastro.2012.15

110.Sapone A, Bai JC, Ciacci C, Dolinsek J, Green PH, Hadjivassiliou M, et al. Spectrum of gluten-related disorders: consensus on new nomenclature and classification. BMC Med. 2012;10:13;doi: 10.1186/1741-7015-10-13

111.Catassi C, Bai JC, Bonaz B, Bouma G, Calabrò A, Carroccio A, et al. Non-Celiac Gluten sensitivity: the new frontier of gluten related disorders. Nutrients. 2013; 5(10): 3839-3853;Doi: 10.3390/nu5103839

112.Sapone A, Lammers KM, Casolaro V, Cammarota M, Giuliano MT, De Rosa M, et al. Divergence of gut permeability and mucosal immune gene expression in two gluten-associated conditions: celiac disease and gluten sensitivity. BMC Med. 2011;9:23;Doi: 10.1186/1741-7015-9-23

113.Biesiekierski JR, Peters SL, Newnham ED, Rosella O, Muir JG, Gibson PR. No effects of gluten in patients with self-reported non-celiac gluten sensitivity after dietary reduction of fermentable, poorly absorbed, short-chain carbohydrates Gastroenterology. 2013;145(2):320-328; doi: 10.1053/j.gastro.2013.04.051

114.Vazquez-Roque M, Camilleri M, Zinsmeister AR. Reply: To PMID 23357715 Gastroenterology. 2013 ;145(3):694;Doi: 10.1053/j.gastro.2013.07.039

115.Di Sabatino A, Volta U, Salvatore C, Biancheri P, Caio G, De Giorgio R, et al. Small Amounts of Gluten in Subjects With Suspected Nonceliac Gluten Sensitivity: A Randomized, Double-Blind, Placebo-Controlled, Cross-Over Trial. Clin Gastroenterol Hepatol. 2015;13(9):1604-1612;Doi: 10.1016/j. cgh.2015.01.029

116.Hollon J, Puppa EL, Greenwald B, Goldberg E, Guerrerio A, Fasano A. Effect of gliadin on permeability of intestinal biopsy explants from celiac disease patients and patients with non-celiac gluten sensitivity. Nutrients. 2015;7(3):1565-1576;doi: 10.3390/nu7031565

117.Brottveit M, Beitnes AC, Tollefsen S, Bratlie JE, Jahnsen FL, Johansen FE et al. Mucosal cytokine response after short-term gluten challenge in celiac disease and non-celiac gluten sensitivity. Am J Gastroenterol. 2013;108(5):842850;doi: 10.1038/ajg.2013.91

118.Volta U, Tovoli F, Cicola R, Parisi C, Fabbri A, Piscaglia M, et al. Serological tests in gluten sensitivity (nonceliac gluten intolerance). J Clin Gastroenterol. 2012;46(8):680-685;doi: 10.1097/MCG.0b013e3182372541

119.Carroccio A, Mansueto P, Iacono G, Soresi M, D’Alcamo A, Cavataio F et al. Non-celiac wheat sensitivity diagnosed by double-blind placebocontrolled challenge: exploring a new clinical entity. Am J Gastroenterol. 2012;107(12):1898-906;Doi: 10.1038/ajg.2012.236

120.Molina-Infante J, Carroccio A. Suspected Nonceliac Gluten Sensitivity onfirmed in Few Patients After Gluten Challenge in Double-Blind, PlaceboControlled Trials. Clin Gastroenterol Hepatol. 2017;15(3):339-348;Doi: 10.1016/j.cgh.2016.08.007

121.Vazquez-Roque MI, Camilleri M, Smyrk T, Murray JA, Marietta E, O’Neill J, et al.
A controlled trial of gluten-free diet in patients with irritable bowel syndromediarrhea: effects on bowel frequency and intestinal function. Gastroenterology. 2013;144(5):903-911;Doi: 10.1053/j.gastro.2013.01.049

122.Rostami K, Malekzadeh R, Shahbazkhani B, Akbari MR, Catassi C. Coeliac disease in Middle Eastern countries: a challenge for the evolutionary history of this complex disorder? Dig Liver Dis. 2004 ;36(10):694-697; Doi:10.1016/j. dld.2004.05.010

123.Cianferoni A, Spergel JM. Food allergy: review, classification and diagnosis. Allergol Int. 2009;58(4):457-466;Doi: 10.2332/allergolint.09-RAI-0138

124.Chehade M, Mayer L. Oral tolerance and its relation to food hypersensitivities. J Allergy Clin Immunol. 2005;115(1):3-12; Doi:10.1016/j.jaci.2004.11.008

125.Heyman M. Symposium on 'dietary influences on mucosal immunity'. How dietary antigens access the mucosal immune system. Proc Nutr Soc. 2001;60(4):419-426

126.Iwasaki A. Mucosal dendritic cells. Annu Rev Immunol. 2007;25:381-418. Doi:10.1146/annurev.immunol.25.022106.141634

127.Dahan S, Roth-Walter F, Arnaboldi P, Agarwal S, Mayer L. Epithelia: lymphocyte interactions in the gut. Immunol Rev. 2007;215:243-253; Doi:10.1111/j.1600065X.2006.00484.x

128.Mowat AM. Anatomical basis of tolerance and immunity to intestinal antigens. Nat Rev Immunol. 2003;3(4):331-341; Doi:10.1038/nri1057

129.Lack G. Epidemiologic risks for food allergy. J Allergy Clin Immunol. 2008;121(6):1331-1336;Doi: 10.1016/j.jaci.2008.04.032

130.Romagnani P, Annunziato F, Piccinni MP, Maggi E, Romagnani S. Th1/Th2 cells, their associated molecules and role in pathophysiology. Eur Cytokine Netw. 2000;11(3):510-511

131.Cianferoni A, Khullar K, Saltzman R, Fiedler J, Garrett JP, Naimi DR, et al. Oral food challenge to wheat: a near-fatal anaphylaxis and review of 93 food challenges in children. World Allergy Organ J. 2013;6(1):14;Doi: 10.1186/1939-4551-6-14

132.Aihara Y, Kotoyori T, Takahashi Y, Osuna H, Ohnuma S, Ikezawa Z. The necessity for dual food intake to provoke food-dependent exercise-induced anaphylaxis (FEIAn): a case report of FEIAn with simultaneous intake of wheat and umeboshi. J Allergy Clin Immunol. 2001;107(6):1100-1105. Doi:10.1067/ mai.2001.115627

133.Pourpak Z, Ghojezadeh L, Mansouri M, Mozaffari H, Farhoudi A. Wheat anaphylaxis in children. Immunol Invest. 2007;36(2):175-182; DOI:10.1080/08820130600941211

134.Scherf KA, Brockow K, Biedermann T, Koehler P, Wieser H. Wheat-dependent exercise-induced anaphylaxis. Clin Exp Allergy.2016;46(1):10-20;Doi: $10.1111 /$ cea. 12640

135.Keet CA, Matsui EC, Dhillon G, Lenehan P, Paterakis M, Wood RA. The natural history of wheat allergy. Ann Allergy Asthma Immunol. 2009;102(5):410415;Doi: 10.1016/S1081-1206(10)60513-3

136.Wiszniewska M, Nowakowska-Swirta E, Palczynski C, Walusiak-Skorupa J. Diagnosing of bakers' respiratory allergy: is specific inhalation challenge test essential? Allergy Asthma Proc. 2011;32(2):111-118;Doi: 10.2500/ aap.2011.32.3422 
137.Quirce S, Diaz-Perales A. Diagnosis and management of grain-induced asthma. Allergy Asthma Immunol Res.2013;(5):348-356;Doi: 10.4168/ aair.2013.5.6.348

138.Sampson HA. Food allergy. Part 1: immunopathogenesis and clinical disorders. J Allergy Clin Immunol. 1999;103:717-728

139.Lee LA, Burks AW. Food allergies: prevalence, molecular characterization, and treatment/prevention strategies. Annu Rev Nutr. 2006;26:539565;Doi:10.1146/annurev.nutr.26.061505.111211

140.Sander I, Merget R, Degens PO, Goldscheid N, Bruning T, Raulf-Heimsoth M. Comparison of wheat and rye flour skin prick test solutions for diagnosis of baker's asthma. Allergy. 2004;59(1):95-98

141.Jones SM, Magnolfi CF, Cooke SK, Sampson HA. Immunologic cross-reactivity among cereal grains and grasses in children with food hypersensitivity. J Allergy Clin Immunol. 1995;96(3):341-351

142.Sander I, Raulf-Heimsoth M, Duser M, Flagge A, Czuppon AB, Baur X. Differentiation between cosensitization and cross-reactivity in wheat flour and grass pollen-sensitized subjects. Int Arch Allergy Immunol. 1997;112:378-385

143.Matsuo H, Dahlstrom J, Tanaka A, Kohno K, Takahashi H, Furumura $M$, et al. Sensitivity and specificity of recombinant omega- 5 gliadinspecific IgE measurement for the diagnosis of wheat-dependent exerciseinduced anaphylaxis. Allergy. 2008;63(2):233-236;Doi: 10.1111/j.13989995.2007.01504.x

144.Chinuki Y, Kaneko S, Dekio I, Takahashi H, Tokuda R, Nagao M, et al. CD203c expression-based basophil activation test for diagnosis of wheat-dependent exercise-induced anaphylaxis. J Allergy Clin Immunol. 2012;129(5):1404 1406;Doi: 10.1016/j.jaci.2012.02.049

145.Tokuda R, Nagao M, Hiraguchi Y, Hosoki K, Matsuda T, Kouno K, et al. Antigen-induced expression of CD203c on basophils predicts IgE-mediated wheat allergy. Allergol Int. 2009;58(2):193-199;Doi: 10.2332/allergolint.08OA-0023
146.Cianferoni A. Wheat allergy: diagnosis and management. J Asthma Allergy. 2016;9:13-25;Doi: 10.2147/JAA.S81550

147.Jones SM, Burks AW, DupontC. State of the art on food allergen immunotherapy: oral, sublingual, and epicutaneous. J Allergy Clin Immunol. 2014;133(2):318323;Doi: 10.1016/j.jaci.2013.12.1040

148.Novembre E, Cianferoni A, Bernardini R, Veltroni M, Ingargiola A, Lombardi $\mathrm{E}$, et al. Epidemiology of insect venom sensitivity in children and its correlation to clinical and atopic features. Clin Exp Allergy. 1998;28(7):834-838

149.Poole JA, Barriga K, Leung DY, Hoffman M, Eisenbarth GS, Rewers M, et al. Timing of initial exposure to cereal grains and the risk of wheat allergy. Pediatrics. 2006;117(6):2175-2182;Doi:10.1542/peds.2005-1803

150.Venter C, Pereira B, Grundy J, Clayton CB, Arshad SH, Dean T. Prevalence of sensitization reported and objectively assessed food hypersensitivity amongst six-year-old children: a population-based study. Pediatr Allergy Immunol. 2006;17(5):356-363; Doi:10.1111/j.1399-3038.2006.00428.x

151.Venter C, Pereira B, Grundy J, Clayton CB, Roberts G, Higgins B, et al. Incidence of parentally reported and clinically diagnosed food hypersensitivity in the first year of life. J Allergy Clin Immunol. 2006;117(5):1118-1124; Doi:10.1016/j. jaci.2005.12.1352

152.Venter C, Pereira B, Voigt K, Grundy J, Clayton CB, Gant C, et al. Comparison of open and double-blind placebo-controlled food challenges in diagnosis of food hypersensitivity amongst children. J Hum Nutr Diet. 2007;20(6):565-579; Doi:10.1111/j.1365-277X.2007.00828.x

153.Venter C, Pereira B, Voigt K, Grundy J, Clayton CB, Higgins B, et al. Prevalence and cumulative incidence of food hypersensitivity in the first 3 years of life. Allergy. 2008;63(3):354-359; Doi:10.1111/j.1398-9995.2007.01570.x

154.Kabbani TA, Vanga RR, Leffler DA, Villafuerte-Galvez J, Pallav K, Hansen J, et al. Celiac disease or non-celiac gluten sensitivity? An approach to clinical differential diagnosis. Am J Gastroenterol. 2014;109(5):741-746; Doi: 10.1038/ ajg.2014.41Eniminul luptiatum alibus et ex ex et quam nimillo rpossin ciiscip 